\title{
SOCIAL DEMOCRATIC PARTY EXCEPTIONALISM AND TRANSNATIONAL POLICY LINKAGES
}

\author{
PETRA SCHLEITER \\ (corresponding author) \\ University of Oxford \\ Department of Politics and International Relations \\ Manor Road \\ Oxford OX1 3UQ \\ United Kingdom \\ petra.schleiter@politics.ox.ac.uk \\ TOBIAS BÖHMELT \\ University of Essex \\ Department of Government \\ Wivenhoe Park \\ Colchester CO4 3SQ \\ United Kingdom \\ tbohmelt@essex.ac.uk \\ LAWRENCE EZROW \\ University of Essex \\ Department of Government \\ Wivenhoe Park \\ Colchester CO4 3SQ \\ United Kingdom \\ ezrow@essex.ac.uk \\ RONI LEHRER \\ University of Mannheim \\ Mannheim Centre for European Social Research \\ A 5, 6 \\ 68131 Mannheim \\ Germany \\ lehrer@uni-mannheim.de
}

We thank the journal's editor, Joy M. Scharfstein, and four anonymous reviewers for their helpful comments and suggestions. 


\title{
SOCIAL DEMOCRATIC PARTY EXCEPTIONALISM AND TRANSNATIONAL POLICY LINKAGES
}

\begin{abstract}
Political parties learn from foreign incumbents, i.e., parties abroad that won office. But does the scope of this cross-national policy diffusion vary with the party family that generates incumbents? We argue that party family conditions transnational policy learning when it makes information on the positions of sister parties more readily available and relevant. Both conditions apply to Social Democratic parties. Unlike other party families, Social Democrats faced major competitive challenges from the 1970s and they exhibit exceptionally strong transnational organizations - factors that, as we contend, uniquely facilitate cross-national policy learning from successful parties within the family. We analyze parties' policy positions using spatial methods and find that Social Democratic parties are indeed exceptional as they emulate one another across borders more than Christian Democrats and Conservatives. These findings have important implications for our understanding of political representation and of Social Democratic parties' election strategies over the last forty years.
\end{abstract}

Keywords: Social Democracy; Party Policy Positions; Diffusion; Political Representation; Political Parties 
"[W]e are all united in the effort to create democratic systems in which not determination from outside or from above but responsible self-determination is to be the dominating social principle [...]. We are not a closed society but an association of independent parties whose representatives feel they can learn from each other and can by joint effort achieve something useful [...]." Willy Brandt (1978), Speech to the Socialist International Congress, Vancouver. ${ }^{1}$

"The debate today is no longer about whether we modernise, but how and how fast. ... My case is straightforward. The left and centre-left has to stay true to its values but rediscover fundamental radicalism in applying those values to the modern world and jettison outdated doctrine and dogma that stands in our way." Tony Blair, Speech to the Socialist International Congress, Paris, $1999 .^{2}$

\section{INTRODUCTION}

nalyses of the Socialist International, ${ }^{3}$ of Social Democratic party cooperation at the
European level, ${ }^{4}$ and of Social Democracy's reorientation towards "Third Way" policies during the $1990 s^{5}$ suggest strong policy linkages within the Social Democratic party family. However, studies of cross-national policy linkages between parties highlight success, rather than party family, as the mechanism driving transnational policy diffusion. ${ }^{6}$ That is, in seeking to construct a winning electoral strategy at home, political parties take cues from foreign incumbents in general, i.e., successful political parties abroad, ${ }^{7}$ and not necessarily only those of the same party family. In this article, we revisit the role of party family in the policy diffusion process and argue that - due to their ideology, extensive transnational linkages, and unique challenges - successful Social Democratic parties transmit policies more strongly within their party family than successful parties in other families.

\footnotetext{
${ }^{1}$ Seidelmann 1998, 3.

${ }^{2}$ See online at: http://news.bbc.co.uk/1/hi/uk_politics/508882.stm.

${ }^{3}$ Imlay 2018.

${ }^{4}$ Hix 1996; Ladrech 1993.

${ }^{5}$ Giddens 1998.

${ }^{6}$ Böhmelt et al. 2016; 2017.

${ }^{7}$ Ezrow et al. 2020.
} 
When politicians and party strategists make programmatic choices to position their party for electoral success, they face considerable uncertainty. Previous research emphasizes that political parties respond to such uncertainties by employing the heuristic ${ }^{8}$ of learning from and emulating other, successful parties' positions. This occurs not just in their domestic sphere, ${ }^{9}$ but also by looking at successful parties abroad.${ }^{10}$ Hence, the expectation is that success, operationalized as incumbency, drives policy diffusion for all political parties, i.e., political parties will emulate and learn from foreign incumbents.

Markedly absent from our understanding of cross-border policy diffusion between parties is the role of party family. ${ }^{11}$ Successful incumbents that lead governments are overwhelmingly Social Democrats, Christian Democrats, or Conservatives. That is, these parties cluster in familles spirituelles defined by their origins in the great ideological movements of the $19^{\text {th }}$ and early $20^{\text {th }}$ century, history, and transnational linkages. ${ }^{12} \mathrm{We}$ examine whether party family matters for international policy diffusion by combining the literature on party families, and specifically Social Democratic parties, ${ }^{13}$ with research on party policy diffusion. ${ }^{14}$

We expect party family to influence international policy diffusion from successful (i.e., incumbent) parties for two reasons. First, the shared ideological ambitions and crossborder linkages within party families affect what information is available to party strategists

\footnotetext{
${ }^{8}$ For example, Kahneman et al. 1982.

${ }^{9}$ For example, Adams and Somer-Topcu 2009; Williams 2015; Williams and Whitten 2015.

${ }^{10}$ For example, Böhmelt et al. 2016; 2017.

${ }^{11}$ See Senninger et al. (2020) who examine the role of the European Parliament in influencing national parties' policy positions. A party family effect is not reported, though.

${ }^{12}$ For example, see, von Beyme 1985; Jacobs 1989; Gallagher et al. 2011; Ware 1996. Note that the concept of "party family" is evolving, also as parties position themselves on new issues such as European integration. The conventional party family framework, however, that emphasizes traditional left-right ideological linkages demonstrably retains analytical usefulness and we rely on this in the following (Whitefield and Rohrschneider 2019).

${ }^{13}$ Benedetto et al. 2020; Kitschelt 1994; Pontusson 1995; Przeworski and Sprague 1986.

${ }^{14}$ Adams and Somer-Topcu 2009; Meguid 2005; 2008; Laver 2005; Williams 2015; Williams and Whitten 2015; Böhmelt et al. 2016; 2017, Wolkenstein et al. 2020.
} 
through the organizational channels that exist to transmit policy ideas. These channels vary across party families. Second, the unique cross-national challenges faced by a party family condition the relevance party strategists attach to the success of foreign sister parties in their own search for a winning electoral strategy. Both of these mechanisms, we contend, make the Social Democratic party family an exception to the otherwise limited role of party families in cross-border policy diffusion. Defined by the shared internationalist goal of building more egalitarian capitalist democracies, Social Democracy developed exceptionally strong transnational organizational channels to facilitate policy exchange. ${ }^{15}$ This made information on the platforms of successful sister parties readily available to party strategists. Moreover, the unique challenges that Social Democracy has been facing since the 1970s - including the decline of the industrial working class, globalization, the fall of communism, and the rise of green parties ${ }^{16}$ - made the platforms of successful sister parties within the family the most relevant precedent for leaders searching for winning platforms. Our theoretical and empirical arguments suggest that, by contrast, transnational organizations have not remained as strong for the other major party families that have generated most incumbents, i.e., the Christian Democrats and Conservatives $;{ }^{17}$ nor were unique policy challenges as critical to them. ${ }^{18}$ We test our expectations using quantitative data on 26 established democracies in Europe from 1977-2017. The results show that Social Democracy is exceptional and, unlike the Christian Democratic and Conservative party families, characterized by extensive crossnational emulation of left-right policy positions from Social Democrats abroad who were

\footnotetext{
${ }^{15}$ Hix 1996; Ladrech 1993; Imlay 2018.

${ }^{16}$ Benedetto et al. 2020; Ladrech 1993; Pontusson 1995; Przeworski and Sprague 1986.

${ }^{17}$ In addition to the comparison with the Christian Democratic and Conservative party families on the right, we also examine programmatic policy diffusion among parties to the left of Social Democracy as an alternative reference point (Supporting Information (SI), Table A9).

${ }^{18}$ As noted below, there were pressures for policy diffusion also within these party families, for instance with respect to labor market liberalization and centrist social policies, but the modes of policy diffusion were significantly weaker.
} 
incumbents in the recent past. ${ }^{19}$ A party family, we find, is important and influences crossnational learning when it shares sufficiently strong transnational organizations and significant political challenges. This result has crucial implications for four important political science literatures including studies of programmatic policy learning, Social Democracy, party election strategies, and policy diffusion in general. We expand on these contributions in the conclusion.

\section{PARTY POLICY DIFFUSION, HEURISTICS, AND PARTY FAMILY}

When parties seek to position themselves for electoral success in a changing environment, they face complex and uncertain choices. ${ }^{20}$ Parties' strategies may, for instance, focus on taking or altering ideological positions, ${ }^{21}$ picking issues to prime voters or shift their attention, ${ }^{22}$ and choosing broad or narrow appeals. ${ }^{23}$ Complexity and uncertainty make the calculation of optimal electoral strategies challenging ${ }^{24}$ and tax the decisional capacities of party strategists. Parties, therefore, use heuristics to identify relevant information in constructing winning strategies. ${ }^{25}$ Heuristics are "cognitive shortcuts," i.e., guides to rational action in conditions of uncertainty and complexity with a fair chance of success. ${ }^{26}$ Two types of cognitive heuristics guide parties in their search for electorally successful strategies - the availability heuristic and the representativeness heuristic. Decisionmakers who use the

\footnotetext{
${ }^{19}$ Studies of Social Democracy frequently emphasize the importance of a two-dimensional political space in generating dilemmas in the competition for votes. While our main analysis focuses on the one-dimensional left-right scale, we examine the robustness of our findings when accounting for multidimensionality of the issue space in the SI (Tables A10 and A11).

${ }^{20}$ Budge 1994, 445; see also Somer-Topcu 2009; 2015.

${ }^{21}$ For example, Adams, Merrill, and Grofman 2005; Adams and Somer-Topcu 2009; Bawn and Somer-Topcu 2012.

${ }^{22}$ Aragonès, Castanheira, and Giani 2015.

${ }^{23}$ Somer-Topcu 2015.

${ }^{24}$ Laver and Sergenti 2012.

${ }^{25}$ See also Weyland 2005.

${ }^{26}$ Kahneman and Tversky 1979.
} 
availability heuristic estimate "frequency or probability by the ease with which instances or associations can be brought to mind." 27 Under the representativeness heuristic, "probabilities are evaluated by the degree to which A resembles B." 28 These heuristics have been shown to explain not only why parties learn from and emulate foreign policies, but also crucially whose policies are likely to be emulated. In particular, these are dominant governing parties, which won office alone or lead their coalitions because information on their policies is both readily available and a relevant precedent demonstrating how to win votes and how to dominate a government. $^{29}$

Party families, or (perceived) ideological similarity, may also affect the availability of information and the relevance of precedents. However, previous accounts of international policy diffusion downplay the role of party family and ideology ${ }^{30}$ or do not find empirical support that party families matter for diffusion. ${ }^{31}$ A reevaluation of party family is warranted, given that parties pursue not only electoral success, but also policy goals. ${ }^{32}$ Clearly, the search for electoral victory can cause parties to assimilate some programmatic stances of successful parties from other ideological blocs, ${ }^{33}$ as illustrated by the way some Social Democratic parties have adopted parts of the center-right's neo-liberal economic program. However, to remain competitive, parties must negotiate the tension between pursuing policy and electoral success. ${ }^{34}$ In that respect, sister parties abroad with similar goals that succeed in winning office are likely to be particularly relevant precedents. Hence, learning from and

\footnotetext{
27 Tversky and Kahneman 1982, 164.

${ }^{28}$ Tversky and Kahneman 1974, 1124.

${ }^{29}$ Böhmelt et al. 2016; 2017.

${ }^{30}$ See Senninger et al. 2020.

${ }^{31}$ Böhmelt et al. 2016; 2017.

${ }^{32}$ Strøm 1990.

33 Adams and Somer-Topcu 2009; Laver 2005; Williams 2015; Williams and Whitten 2015; Böhmelt et al. 2016; 2017.

${ }^{34}$ Wittman 1983.
} 
emulating their policies might be an important heuristic. At the domestic level, too, there is evidence that parties pay close attention to the peers within their own ideological bloc. ${ }^{35}$

While it is plausible that ideological affinity matters for international policy diffusion, it is likely more influential for some party families than for others. Specifically, we contend that party strategists can be expected to privilege learning from successful sister parties abroad under two conditions. First, when transnational organizations within the famille spirituelle make information on sister parties abroad readily available and, second, when unique challenges faced by the family make the choices of sister parties the most relevant precedent. Under these circumstances, party family links condition the availability and representativeness heuristics applied. Below, we discuss these two mechanisms and show that they apply to Social Democracy, but not to the other party families, and, in particular, the Christian Democratic and Conservative families that produced the majority of incumbents on the political right. ${ }^{36}$ This makes the Social Democratic party family the exception to the otherwise muted role of party families in transnational policy diffusion.

\section{SOCIAL DEMOCRATIC PARTY EXCEPTIONALISM}

\section{TRANSNATIONAL LINKAGES AND LEARNING FROM AVAILABLE PRECEDENTS}

Comparative research clusters parties in families because of their shared origins in the ideological movements as of the $19^{\text {th }}$ century and international linkages likely have consequences for their behavior. ${ }^{37}$ Party families mobilizing to represent social groups in specific historical contexts developed organizational structures of varying strength to suit their goals. In cross-national policy diffusion, such family links may shape the information

\footnotetext{
${ }^{35}$ Adams 2001; Adams and Merrill 2009; Adams and Somer-Topcu 2009; Williams 2015.

${ }^{36}$ In the SI, we also examine how party policy diffusion among Social Democrats contrasts with diffusion among parties to their left (Table A9).

37 von Beyme 1985; Jacobs 1989; Gallagher et al. 2011; Ware 1996.
} 
available to party strategists in their search for winning strategies, i.e., they affect how the availability heuristic is applied. ${ }^{38}$ Previous work assumes that information availability is driven by the media coverage that successful incumbents receive compared to opposition parties. ${ }^{39}$ We argue that strong transnational organizations specific to party families are an additional channel that makes information about the programs of successful incumbent sister parties easily available within the family. This increases the probability of learning from and emulating foreign incumbents by party leaders and their advisers in the same party family. Social Democracy, unlike other party families, featured exceptionally strong crossnational links from its inception for two reasons. Ideologically, Social Democracy retained from its revolutionary origins the shared ideological goal of transforming capitalism ${ }^{40}$ and subscribed to socialist internationalism, i.e., cross-national collaboration to develop shared policy approaches. ${ }^{41}$ Organizationally, the party family developed transnational institutional links supporting this policy collaboration. The Socialist International channeled consultation between socialist parties on international issues. ${ }^{42}$ Regionally, Social Democratic parties formed an effective and powerful party federation in the European Parliament (EP), the Party of European Socialists (PES). Recent work shows that party groups in the EP are effective institutional channels of policy diffusion, ${ }^{43}$ but the PES proved institutionally more powerful than others. ${ }^{44}$ It has not only been coordinating European policies of national Social Democratic parties from the 1970s onward, but grew increasingly influential with the Maastricht Treaty negotiations with a statute that provides "for majority decision making in

\footnotetext{
${ }^{38}$ Tversky and Kahneman 1982.

39 Even when controlling for the level of electoral support: Green-Pedersen et al. 2017; Hopmann et al. 2011; Schoenbacher et al. 2001; Semetko 1996.

${ }^{40}$ Benedetto et al. 2020.

${ }^{41}$ Imlay 2018.

42 Imlay 2018.

${ }^{43}$ Senninger et al. 2020.

${ }^{44}$ Senninger at al. (2020) focus on the policy diffusion that occurs between parties belonging to the same EP party groups. We provide a theoretical account of cross-family variation.
} 
all areas of EC policy where qualified majority is used in the Council of Ministers, and in certain areas decisions can be made which are binding on the national socialist parties." ${ }^{45}$

These transnational organizations were employed by successful leaders within the party family to disseminate policy ideas and influence sister parties abroad. Willy Brandt, for instance, made use of his presidency of the Socialist International (1976-1992) to promote the normalization of relations with the USSR, an extension of the objectives that he pursued through "Ostpolitik" as German Chancellor. Similarly, Tony Blair, addressing the Congress of the PES in Malmö in 1996, called on fellow European socialist leaders to "modernize or die," and to embrace "Third Way" reforms by holding "our values dear, then revolutionize our method of implementing them." 46

Incumbents of the political right, in contrast, have traditionally been significantly less united both ideologically and organizationally. Successful parties representing that part of the political spectrum since 1945 are drawn from the Christian Democratic and Conservative party families and display greater ideological heterogeneity than Social Democracy. ${ }^{47}$ Key ideological fault lines among Christian Democrats concern, e.g., the centrality they accord to their Christian roots (dividing, e.g., the Dutch CDA from the German CDU/CSU), antisocialism (central for many of these parties, but for others, such as the Belgian, Dutch, and Italian parties, it contradicts their domestic Christian Democratic-Socialist alliances), and different welfare state models. ${ }^{48}$ Moreover, while Christian Democrats embraced supranational cooperation and European integration, Conservatives did not necessarily do so. This hampered the creation of effective transnational organizations by these parties. While the Conservatives formed the European Democratic Union, it remained weaker than other

\footnotetext{
${ }^{45}$ Hix 1996, 320.

${ }^{46}$ See online at: https://bbc.in/3cmnHvR.

${ }^{47}$ Layton-Henry 1982; Kalyvas and van Kersbergen 2010.

48 van Kersbergen and Manow 2009; Kalyvas and van Kersbergen 2010.
} 
federations and eventually merged in the 1990s with the European People's Party (EPP) formed by the Christian Democrats. ${ }^{49}$ Thus, although Christian Democratic parties had a strong transnational party organization, the EPP, it was less effective as a channel for policy diffusion than the equivalent organizational ties among Social Democrats for two reasons: ideologically, Christian Democracy was more heterogeneous; and, organizationally, it coalesced with another major party family at the European level since the 1990s.

In sum, the strength of transnational organizations within the Social Democratic party family is exceptional and instrumental in making information on the policy platforms adopted by successful sister parties abroad readily available to party strategists.

\section{SHARED POLICY CHALLENGES AND LEARNING FROM REPRESENTATIVE PRECEDENTS}

In cross-national policy diffusion, the second type of cognitive short-cut applied by party strategists is the representativeness heuristic,${ }^{50}$ i.e., the degree to which the ambition and strategic choices open to a foreign party resemble those of the focal party that is aiming to construct a winning platform. Existing research suggests that the representativeness heuristic leads party strategists, aiming to position their party for electoral success, to focus on foreign parties whose programmatic choices have won them office. ${ }^{51}$ We claim that whether or not a winning foreign party's choices represent the dilemmas faced by the focal party can be mediated by party family. Specifically, when unique cross-national challenges are confronted by parties within a family, the choices of successful sister parties become a particularly relevant precedent.

Social democratic parties have faced significant and unique competitive pressures since the mid-1970s. In the post-war years, Social Democratic parties successfully adopted

\footnotetext{
${ }^{49}$ Hix 1996.

50 Tversky and Kahneman 1974.

${ }^{51}$ Dolowitz et al. 1999; Dolowitz and Marsh 2000; see also Ezrow et al. 2020.
} 
catch-all strategies that broadened their electoral support beyond the working class. ${ }^{52}$ This saw their support peak in the 1960s-1970s, ${ }^{53}$ expanded their coalition options, and propelled them into governments across Europe. However, from the 1970s, the catch-all strategies of Social Democratic parties came under pressure. ${ }^{54}$ The challenges facing the party family in the 1970s and 1980s were economic, ideological, and political. Economic development precipitated a shift toward nonindustrial occupations, ${ }^{55}$ that sent the industrial working class, traditionally the core electorate of Social Democratic parties, into secular decline. The oil crisis of the 1970s was accompanied by high levels of unemployment, stagnation, and inflation, which challenged the assumptions of Keynesian economics and led to the adoption of neoliberal approaches that opened up national economies to global trade. ${ }^{56}$ The resulting pressures on Social Democratic parties were further compounded by the collapse of Communism and the introduction of the European Single European Market. ${ }^{57}$ Ideologically, these developments questioned the programmatic identity of Social Democracy and the effectiveness of policies that they had traditionally espoused to promote workers' rights and social justice. Politically, competition from the left for socially liberal voters from rising Green parties put further strain on the electoral coalition underpinning Social Democracy. The confluence of these factors demanded a renewal of Social Democracy.

In response to these challenges, leaders within the movement proposed the reorientation of Social Democratic parties toward "Third Way" politics that generally accepted free markets, but also sought to regulate their effects. We argue that the rapid diffusion of many of these ideas within the party family, albeit with national differences, ${ }^{58}$

\footnotetext{
${ }^{52}$ Przeworski and Sprague 1986.

${ }^{53}$ Benedetto et al. 2020.

${ }^{54}$ Przeworski and Sprague 1986.

${ }^{55}$ Pontusson 1995.

${ }^{56}$ Benedetto et al. 2020.

${ }^{57}$ Ladrech 1993; see also Benedetto et al. 2020.

${ }^{58}$ Keman 2011.
} 
was powerfully driven by the specificity of the challenges that Social Democracy faced. The strategists of Social Democratic parties across Europe learned from the programmatic choices of the first Social Democrats carried to power by the adoption of "Third Way" ideas, because those choices resolved dilemmas that closely resembled those of their own party. Hence, Social Democratic party family mediated policy diffusion because successful Social Democratic parties were most representative of the precedent that party strategists aimed to emulate.

Anecdotally, there is ample evidence of the diffusion of "Third Way" policies within the Social Democratic party family. As Giddens notes, "[w]hen New Labour first came into government, there was intense interest among Social Democratic parties in Continental Europe." ${ }^{, 9}$ In April 1999, Bill Clinton sponsored a dialogue in Washington D.C. on the "Third Way" that was attended by five European heads of government, Tony Blair, Gerhard Schröder, Wim Kok, and Massimo D’Alema. Later that year, Tony Blair and Gerhard Schröder published a joint vision for a reformed Social Democracy in "The Third Way/Die Neue Mitte, ${ }^{, 60}$ drafted by their strategists Peter Mandelson and Bodo Hombach. ${ }^{61}$ Through the mid to late 1990s, the concomitant centrist policy shifts proved electorally successful: European Social Democratic parties dominated elections and entered governments, either solely or in coalition. In 1998, the only exceptions in Europe were Ireland, Norway, and Spain. $^{62}$

This success proved transient, however, and Social Democracy continued to face severe challenges. Since 2000, the electoral support of these parties has sunk to historical

\footnotetext{
${ }^{59}$ Giddens 2000, 4.

${ }^{60}$ Blair and Schröder 1999.

${ }^{61}$ For example, the pamphlet calls on Social Democrats to "learn from each other and measure our own performance against best practice and experience in other countries. With this appeal, we invite other European Social Democratic governments who share our modernizing aims to join us in this enterprise" (Blair and Schröder 1999).

${ }^{62}$ Benedetto et al. 2020.
} 
lows with the continued decline of the industrial working class, the defection of socially Conservative socialist voters to populist parties, and a loss of public-sector support in light of severe constraints on public spending following the Great Recession. ${ }^{63}$ The uniqueness of these challenges to the Social Democratic party family can be expected to give powerful incentives to party strategists to learn from and emulate the first successful responses by sister parties abroad, once they emerge.

While the same social, economic, and geopolitical changes also affected the competitive environment of Conservatives and Christian Democrats, the impact on these parties was neither as uniform nor as existentially threatening as it was for the Social Democrats. The decline of the industrial working class represented more opportunities than challenges for the Conservatives and Christian Democrats. ${ }^{64}$ While economic globalization forced the political right to reform their welfare policies, individual parties were committed to different welfare-state models, ${ }^{65}$ which made the challenges they faced heterogeneous. Globalization, with the spread of neo-liberalism and labor market liberalization, also represented a less fundamental threat to Conservatives and Christian Democrats, because they held economic positions to the right of their Social Democratic counterparts. ${ }^{66}$ The collapse of Communism and post-material value change, including the rise of secularism, differed in how they influenced Conservatives and Christian Democrats based on whether antisocialism, traditionalism, and/or their confessional roots remained central to their identities. ${ }^{67}$ Thus, the challenges that Conservatives and Christian Democrats faced were more varied and less existentially threatening than those faced by Social Democrats, which weakened incentives for cross-national family-specific learning.

\footnotetext{
${ }^{63}$ Benedetto et al. 2020; Berman and Snegovaya 2019.

${ }^{64}$ Kalyvas and van Kersbergen 2010, 189.

${ }^{65}$ van Kersbergen and Manow 2009.

${ }^{66}$ Ward et al. 2011.

${ }^{67}$ Kalyvas and van Kersbergen 2010, 188.
} 
In sum, party leaders and strategists focus on successful foreign parties as a useful heuristic to develop a model for their own success. We argue that party family mediates this under two conditions: first, when the family features strong transnational organizational links (making information on successful programmatic choices within the family readily available to party strategists) and, second, when it faces significant and unique challenges to success (which makes successful responses by sister parties the most representative precedents). Among the party families, which have generated significant numbers of incumbents throughout the post-war era, both conditions apply to Social Democracy from the 1970s onward, in contrast to Christian Democrats/Conservatives. Hence, we hypothesize that policy diffusion within the Social Democratic party family through learning by its members from foreign successful incumbents is the exception to the otherwise muted role of party family in mediating transnational policy diffusion.

Social Democratic Party Family Hypothesis: Policy diffusion within the Social Democratic party family from its incumbents is exceptionally strong, compared to other party families.

\section{RESEARCH DESIGN}

The unit of analysis in our data set is the party-year and we analyze 264 political parties in 26 European democracies over a forty-year period from 1977 to 2017 . New parties enter the data set with the first election they compete in, while parties leave the data once they no longer participate in national elections. To define parties, and their entry and exit dates, we rely on the Comparative Manifesto Project (CMP). ${ }^{68}$ All parties are included when data are available, including regional, agrarian, and other small specialized party families coded by the CMP investigators. The total number of observations is 4,049 party-years. The

${ }^{68}$ Budge et al. 2001; Klingemann et al. 2006; Volkens et al. 2015. 
two central components of our research design are the dependent variable, which captures left-right policy positions of Social Democratic parties and Christian Democrats or Conservatives; and our empirical method that tests whether policy diffusion occurs within the major party families (i.e., Social Democrats, Christian Democrats, and the Conservatives). This research design maximizes parsimony and clarity, allowing for a direct test of our hypothesis, by examining the contrast between diffusion in the three party families that have generated the overwhelming majority of incumbents. ${ }^{69}$

For the dependent variable in our models, the CMP provides a left-right measure on party positions. ${ }^{70}$ In the SI (Tables A10 and A11), we discuss additional analyses that account for the potential multidimensionality of the policy space. The left-right dimension is the most important one for issue competition ${ }^{71}$ and a common vocabulary for political elites and voters relating to the salient issues of governments' role in the economy and the distribution of income. ${ }^{72}$ The CMP's left-right measure is broadly consistent with those derived using other methods. ${ }^{73}$ We rescale the original variable to an interval ranging from 1 (extreme left) to 10 (extreme right) for making it consistent with our median voter scale (see below).

Interpolation is required because parties' policy positions are measured only in election years.

${ }^{69}$ In the SI, we examine further implications of the theory and its underlying mechanisms, including diffusion on a secondary policy dimension next to the general left-right scale, the impact of the unique challenges faced by Social Democratic parties on policy diffusion within this party family (via an interaction with economic globalization), and the exceptionality of policy diffusion in the PES compared to the groups formed by other party families in the EP (Tables A10 to A13).

${ }^{70}$ Budge et al. 2001; Klingemann et al. 2006; Volkens et al. 2015.

${ }^{71}$ Huber and Powell 1994; Powell 2000; see also McDonald and Budge 2005.

72 Huber and Inglehart 1995; Warwick 2002. Ideological structuring underlying the left-right scale in Eastern Europe may differ from that in Western Europe (Evans and Whitefield 1993) as well as across countries and time (Evans and Whitefield 1998; Harbers, De Vries, and Steenbergen 2012; Linzer 2008; Markowski 1997). However, there are strong arguments for using the left-right dimension to understand party competition in post-Communist democracies (Marks et al. 2006, 169; Pop-Eleches and Tucker 2011; McAllister and White 2007).

${ }^{73}$ Hearl 2001; McDonald and Mendes 2001; Laver, Benoit, and Garry 2003. 
For this interpolation, we assume that party positions do not change until the next election year. $^{74}$

Our main focus is on Social Democratic parties, but we examine models concentrating on Christian Democrats and Conservatives. ${ }^{75}$ We follow Benedetto et al. ${ }^{76}$ and define Social Democratic parties as those that are "a member of the Socialist International or Party of European Socialists at a particular time." The terms socialism and Social Democracy are often used interchangeably, though Social Democrats are sometimes viewed as more centrist than other members of the Socialist International in a country. The $\mathrm{CMP}^{77}$ provides detailed information on the type and family of each party coded. We use this information to initially create a binary variable capturing whether a party is Social Democratic (1) or not (0). Out of the 4,049 party-years in your data, 747 pertain to Social Democratic parties $(18.45 \%$ of all observations). The SI gives a detailed overview of the Social Democratic parties that are included in our data with entry and exit years (Table A1). Note that some countries have more than one Social Democratic party at the same time, but this phenomenon affects only a small number of cases: specifically, pairing all parties in our data set with all others produces 431,780 cases - only 256 of those party-dyad years signify pairs of Social Democratic parties in the same country $(0.0006 \%)$. The focus of the analysis is on international programmatic diffusion between Social Democratic parties, but domestic-level diffusion is controlled for in the SI (Table A7) where we control for the possibility that domestic rival parties influence one another. ${ }^{78}$ To examine whether policy diffusion within the Social Democratic party family is indeed exceptional and different from the Christian Democrats and Conservatives,

\footnotetext{
${ }^{74}$ See also Böhmelt et al. 2016; 2017.

75 In an additional analysis, we focus on parties to the left of the Social Democrats as the reference point in examining the robustness of our argument that policy diffusion within the Social Democratic party family is exceptional (SI, Table A9).

${ }^{76}$ Benedetto et al. 2020.

${ }^{77}$ Budge et al. 2001; Klingemann et al. 2006; Volkens et al. 2015.

${ }^{78}$ Adams and Somer-Topcu 2009; see also Williams 2015.
} 
we draw on the party family information contained in the CMP data, ${ }^{79}$ and create binary variables that capture these latter groups of parties. In our data set, 588 (14.52\% of all partyyears) cases are coded as Christian Democrats, while $472(11.66 \%)$ are defined as Conservatives. In the SI, based on previous studies by Adams and Somer-Topcu and Böhmelt et al., ${ }^{80}$ we also aggregate these blocs of parties and examine Conservatives and Christian Democrats jointly (Table A8).

We use spatio-temporal lag models ${ }^{81}$ to capture party policy diffusion and the role of Social Democracy's exceptionalism. The models estimate a party's position as a function of foreign parties' positions. We achieve this via a weighting matrix, $\mathbf{W}$, which specifies the relationship between parties (senders and receivers) and, thereby, the subset of foreign parties that potentially exert an influence. We multiply this connectivity matrix with a temporally lagged version of our dependent variable $\left(y_{e-1}\right)$ to construct the spatial lags, the core components in our models $\left(\mathbf{W} y_{e-1}\right)$, which thus combine data on parties' policy positions with information on party-family membership. The temporal lag we use for the spatial lags (subscript $e-1$ ) pertains to the year before the last election in a sender country. That is, we focus on the positions of potentially influential parties in the year before their last election. To illustrate this design, consider estimating the influence of the German SPD on the British Labour party's 2015 manifesto: the temporal lag will take on the German SPD's 2012 policy position. The last German election before 2015 was held in 2013 and the lag pertains to the year before the last election (2012). The rationale behind this design is based on the observation that developing party manifestos is a "time-consuming process [...] which typically takes place over a two-three year period during which party-affiliated research departments and committees draft sections of his manuscript, which are then circulated for

\footnotetext{
${ }^{79}$ Budge et al. 2001; Klingemann et al. 2006; Volkens et al. 2015.

${ }^{80}$ Somer-Topcu 2009; Böhmelt et al. 2016.

${ }^{81}$ Franzese and Hays 2007; 2008.
} 
revisions and approval upward to party elites and downward to activists." 82 Considering this argument and following previous studies, ${ }^{83}$ instantaneous diffusion effects are unlikely and we hence use parties' policy positions from the year before the last election in their country when constructing the spatial lags.

To allow for distinct effects among Social Democratic parties and Christian Democrats or Conservatives, we specify different weighting matrices. We multiply a first matrix with the temporally lagged dependent variable, where matrix entries are set to 1 only if both parties $i$ (receiver party) and $j$ (sender party) are Social Democratic according to the $\mathrm{CMP}^{84}$ and they do not compete for office in the same country. This leads to the first spatial variable, $\mathbf{W y}{ }^{\text {Social Democrats }}$, which captures the policy position of all Social Democratic parties abroad as a potential influence on Social Democrats "at home." The impact of non-Social Democratic parties is set to 0, and the matrix does not allow for a Social Democratic influence from abroad on non-Social Democrats at home (as the entries are set to 0 here, too). A second spatial variable captures the influence of incumbent parties abroad in the context of party policy diffusion. Here, we modify the matrix so that its entries only receive a value of 1 if both parties $i$ and $j$ are Social Democratic parties, $j$ is active in another country, and $j$ was recently in government (either forming the government on its own or as a member of a coalition). Data for incumbency are taken from Döring and Manow. ${ }^{85}$ We label this second spatial lag $\mathbf{W y}$ Incumbent Social Democrats . A last set of spatial variables follows the setup of the first two items, but instead we focus on Christian Democrats or Conservatives: $\mathbf{W y}$ Christian Democrats and $\mathbf{W y}{ }^{\text {Conservatives }}$ capture the policy positions of all Christian Democratic or Conservative parties abroad as a potential influence on Christian Democratic and Conservative parties "at

\footnotetext{
${ }^{82}$ Adams and Somer-Topcu 2009, 832.

${ }^{83}$ For example, Böhmelt et al. 2016; 2017; Senninger et al. 2020.

${ }^{84}$ Budge et al. 2001; Klingemann et al. 2006; Volkens et al. 2015.

${ }^{85}$ Döring and Manow 2012.
} 
home;" and $\mathbf{W} y^{\text {Incumbent Christian Democrats }}$ and $\mathbf{W} y^{\text {Incumbent Conservatives }}$ comprise the information on whether the "sending" Christian Democratic or Conservative party abroad was recently in power.

We do not row-standardize the spatial lags for theoretical reasons ${ }^{86}$ Row standardization implies that the number of (Social Democratic incumbent) parties abroad at a given time is not relevant. However, rational strategists should only give consideration to other parties' positions if they expect the marginal value of the information gathered to exceed the marginal cost of obtaining it, which is not consistent with the allocation of a fixed amount of effort. In other words, as the number of foreign parties increases, diffusion effects are likely greater, but also diminish with each additional party. We use spatial OLS (S-OLS) regression, which is justifiable because our explanatory variables are temporally lagged. ${ }^{87}$

To credibly ensure that contagion "cannot be dismissed as a mere product of a clustering in similar [party or state] characteristics, ${ }^{88}$ we follow Franzese and Hays ${ }^{89}$ by accounting for the common exposure of parties to similar economic (and other exogenous) factors. ${ }^{90}$ This is accomplished by including the (one-year) temporally lagged dependent variable, party-fixed effects, and year-fixed effects. We also include several additional control variables. Parties may respond to the positions of other domestic parties ${ }^{91}$ and there are likely more general influences across borders than the Social Democratic ones we seek to examine. ${ }^{92}$ To control for these effects, we define two additional spatial lags. In $\mathbf{W y}{ }^{\text {Domestic }}$, matrix entries only receive a value of 1 if $i$ and $j$ are different parties competing in the same

\footnotetext{
${ }^{86}$ Böhmelt et al. 2016; see also Williams 2015; Williams et al. 2016.

${ }^{87}$ Williams 2015; Williams and Whitten 2015; Böhmelt et al. 2016.

${ }^{88}$ Buhaug and Gleditsch 2008, 230; see also Plümper and Neumayer 2010, 427.

${ }^{89}$ Franzese and Hays 2008.

${ }^{90}$ Franzese and Hays 2007, 142.

91 For example, Adams 2001; Adams and Merrill 2009; Adams and Somer-Topcu 2009; Williams 2015.

92 Böhmelt et al. 2016; 2017.
} 
political system (otherwise 0). Second, we specify $\mathbf{W} \mathbf{y}^{\text {Foreign }}$, which is defined in a similar manner except that matrix cells contain 1 only if $i$ and $j$ are different parties not competing in the same system (0 otherwise). Note that foreign Social Democratic, Christian Democratic, and Conservative parties are a subset of all parties abroad. Hence, while this last spatial variable addresses general cross-border diffusion effects not distinguishing between party families or incumbency status, including it in the models likely soaks up explanatory power of the main variables, making our estimations more conservative. ${ }^{93} \mathrm{We}$ further account for the position of the median voter using Eurobarometer data on respondents' left-right selfplacement on a scale of 1 (left) to 10 (right). ${ }^{94} \mathrm{We}$ lag this variable by one year to allow for delayed responses by parties. Finally, Ward et al. ${ }^{95}$ argue that the effects of economic globalization are conditioned by the position of the median voter. We thus control for the economic component of the KOF Globalization Index ${ }^{96}$ and include the multiplicative interaction Lagged Median Voter * Lagged Economic Globalization.

\section{EMPIRICAL RESULTS}

The Social Democratic Party Family Hypothesis expects policy diffusion within the Social Democratic party family (from its incumbents) to be stronger than diffusion within other party families. Table 1 presents the results for Social Democratic parties. Model 1 includes only the control variables, and we omit the core spatial variables. Model 2 adds only $\mathbf{W y}^{\text {Social Democrats }}$ and Model 3 includes only $\mathbf{W} \mathbf{y}^{\text {Incumbent Social Democrats }}$ (while omitting $\mathbf{W} \mathbf{y}^{\text {Social }}$ Democrats). Finally, Model 4 considers all control variables and both Social Democratic spatial

\footnotetext{
${ }^{93}$ Excluding $\mathbf{W} y^{\text {Foreign }}$ from the analyses produces qualitatively similar results, although the main variables' effects increase in size as expected.

${ }^{94}$ Schmitt and Scholtz 2005.

${ }^{95}$ Ward et al. 2011; see also Williams 2015; Williams and Whitten 2015; Williams et al. 2016.

${ }^{96}$ Dreher 2006. This variable is based on trade flows, portfolio and direct investment, tariff and invisible barriers to trade, and capital controls.
} 
variables simultaneously. We can directly interpret signs and statistical significance in Table 1. A spatial lag captures the weighted values of all neighboring units, in this case Social Democrats and Social Democratic incumbents. A coefficient estimate refers to the unitchange in a focal party's position if, for example, all Social Democratic incumbents abroad

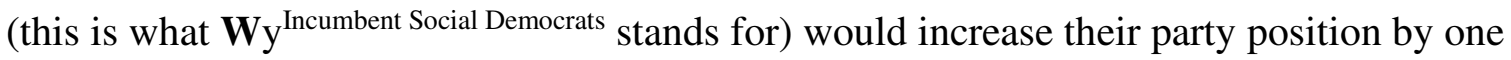
unit. However, the interpretation is more complex because our weighting matrices are not standardized and there is a possibility of temporal as well as spatial spillover effects. Hence, first, the coefficients of the spatial lags are multiplied by the average number of neighbors to assess short-term effects directly. ${ }^{97}$ Second, we also calculate the long-term (asymptotic) effects of the spatial lags following Plümper, Troeger, and Manow. ${ }^{98}$ Both asymptotic longterm and short-term effects of the core spatial variables in Table 1 are presented in Figure 1. Finally, in order to fully account for spatial spillover effects, we calculate spatial long-term equilibrium effects (Table 2) for the core spatial lags, which allow us to estimate "responses of the dependent variable across all units." ${ }^{99}$ Hence, Table 2 presents the spatial influence after diffusion has occurred and accounts for first-order, second-order, and feedback effects. $^{100}$

The two spatial lags, $\mathbf{W} y^{\text {Social Democrats }}$ and $\mathbf{W} y^{\text {Incumbent Social Democrats }}$, are positively signed and statistically significant at conventional levels in Model 2 and Model 3, respectively. This suggests that party policy diffusion does occur between Social Democratic parties, and that Social Democratic incumbents are more influential than Social Democrats that are currently not in government. This is confirmed in Model 4 where $\mathbf{W y}$ Social Democrats $^{\text {is }}$ no longer statistically significant, but $\mathbf{W} y^{\text {Incumbent Social Democrats }}$ remains significant at

\footnotetext{
${ }^{97}$ Plümper and Neumayer 2010, 430f; see also Ward and Gleditsch 2008, 39.

98 Plümper, Troeger, and Manow 2005, 336; see also Plümper and Neumayer 2010, 425.

${ }^{99}$ Hays, Kachi, and Franzese 2010, 409.

${ }^{100}$ Hays, Kachi, and Franzese 2010, 409.
} 
conventional levels and positively signed. This re-emphasizes that Social Democrats learn from and emulate the policies of other Social Democratic parties particularly if they were recently in power. As all foreign Social Democratic incumbents are also Social Democrats (and, as discussed above, they belong to the set of parties abroad), the inclusion of $\mathbf{W} y^{\text {Social }}$ Democrats $n$ next to $\mathbf{W y} \mathbf{y}^{\text {Incumbent Social Democrats }}$ naturally lowers the impact of the latter variable in Model 4 in comparison to Model 3. Therefore, Model 4 controls for the influence of Social Democratic opposition parties abroad more directly than in Model 3 (which omits them from the estimation and treats them as "noise"). Substantively, focusing on Model 4 and after spatial-lag coefficients are multiplied by the average number of neighbors, a Social Democratic party's left-right policy position would be 0.0025 points higher in the short run, if all foreign (neighboring) Social Democratic parties shift one unit to the right, compared to the year before. ${ }^{101}$ This estimate is not statistically significant, however. The effect of foreign Social Democratic incumbent parties is calculated at 0.0045 in the short run. That is, a Social Democratic party's left-right policy position would be 0.0045 points higher (after the spatiallag coefficient is multiplied by the average number of neighbors), if all foreign Social Democratic incumbents had shifted one unit to the right in the year before their last election. Hence, incumbency almost doubles the overall diffusion impact for Social Democrats, and this effect is also significant. Asymptotically (Figure 1), the effect associated with $\mathbf{W y}$ Social Democrats is estimated at 0.0141 (statistically significant), the impact linked to $\mathbf{W y}$ Incumbent Social Democrats is 0.0250 when a spatial lag is increased by one unit. These results are based on Model 4 and adding or dropping specific variables does not alter the substantive findings.

${ }^{101}$ Ward and Gleditsch 2008, 38. 


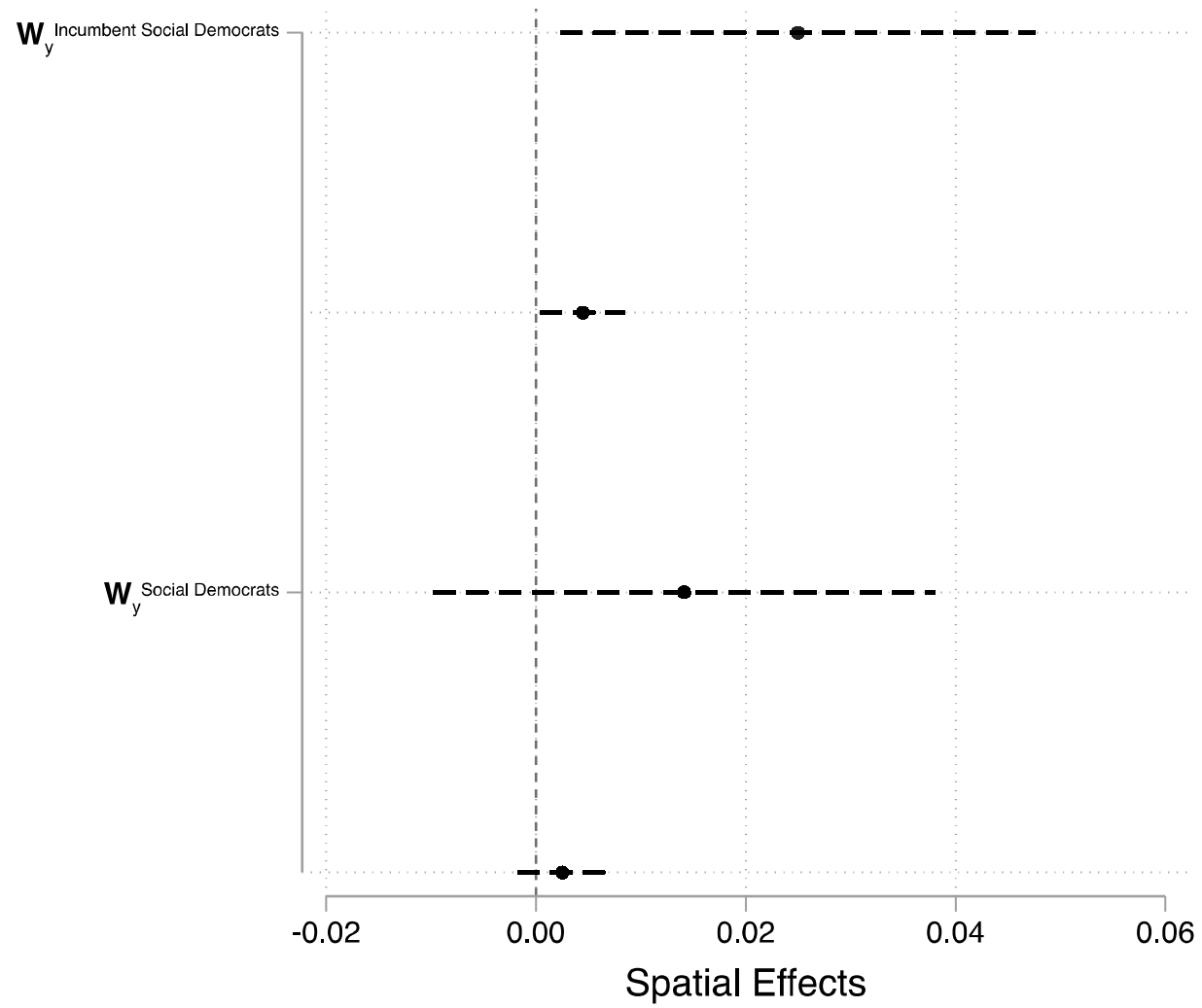

FIGURE 1

TEMPORAL SHORT-TERM AND ASYMPTOTIC LONG-TERM EFFECTS

Notes. The horizontal bars are 90 percent confidence intervals. Spatial effect of 0 marked with dotted vertical line. Estimates are based on Model 4. Short-term effects are reported below asymptotic long-term effects.

For the long-term equilibrium effects of party policy diffusion among Social Democrats where the sender party was recently in power, we first assume that the spatial weights and all other variables remain at 2010 values. We then hypothetically increase some pre-selected Social Democratic parties' policy positions by one unit. This "shock" has direct (first-order) effects in the system via linkages among Social Democratic parties, but also indirect (second-order) effects via longer chains of intermediaries and it eventually feeds 
back to the source party. Since each party will have a different set of linkages to its neighbors, the impact of a hypothetical change in a party's policy position depends on which party's position is altered. We calculate the long-term effects on all parties as the shock reverberates through the system of spatial and temporal lags, i.e., the effects presented in Table 2 comprise both direct and indirect influences. ${ }^{102}$ Our calculations are based on Model 3 that discards spatial variables other than $\mathbf{W y}$ Incumbent Social Democrats for simplicity.

TABLE 1

PARTY POLICY DIFFUSION - SOCIAL DEMOCRATIC FAMILY

\begin{tabular}{lllll}
\hline & \multicolumn{1}{c}{ Model 1 } & \multicolumn{1}{c}{ Model 2 } & \multicolumn{1}{c}{ Model 3 } & \multicolumn{1}{c}{ Model 4 } \\
\hline Lagged Party Position & 0.8240 & 0.8226 & 0.8216 & 0.8215 \\
& $(0.0106)^{* * *}$ & $(0.0107)^{* * *}$ & $(0.0107)^{* * *}$ & $(0.0107)^{* * *}$ \\
Lagged Median Voter & 0.2955 & 0.2955 & 0.3076 & 0.3048 \\
& $(0.1105)^{* * *}$ & $(0.1105)^{* * *}$ & $(0.1105)^{* * *}$ & $(0.1106)^{* * *}$ \\
Lagged Economic Globalization & 0.0184 & 0.0183 & 0.0191 & 0.0189 \\
& $(0.0076)^{* *}$ & $(0.0076)^{* *}$ & $(0.0076)^{* *}$ & $(0.0076)^{* *}$ \\
Lag Median Voter * & -0.0039 & -0.0039 & -0.0040 & -0.0040 \\
Lagged Economic Globalization & $(0.0015)^{* * *}$ & $(0.0015)^{* * *}$ & $(0.0015)^{* * *}$ & $(0.0015)^{* * *}$ \\
WyDomestic & 0.1480 & 0.1493 & 0.1492 & 0.1495 \\
& $(0.0105)^{* * *}$ & $(0.0105)^{* * *}$ & $(0.0105)^{* * *}$ & $(0.0105)^{* * *}$ \\
Wy ${ }^{\text {Foreign }}$ & 0.1439 & 0.1452 & 0.1451 & 0.1455 \\
& $(0.0104)^{* * *}$ & $(0.0104)^{* * *}$ & $(0.0104)^{* * *}$ & $(0.0104)^{* * *}$ \\
Wy ${ }^{\text {Social Democrats }}$ & & 0.0015 & & 0.0008 \\
& & $(0.0007)^{* *}$ & & $(0.0008)$ \\
Wy ${ }^{\text {Incumbent Social Democrats }}$ & & & 0.0033 & 0.0025 \\
& & & $(0.0012)^{* * *}$ & $(0.0014)^{*}$ \\
Observations & 4,049 & 4,049 & 4,049 & 4,049 \\
Year and Party Fes & Yes & Yes & Yes & Yes \\
$\mathrm{R}^{2}$ & 0.884 & 0.884 & 0.884 & 0.884 \\
RMSE & 0.308 & 0.307 & 0.308 & 0.308 \\
\hline
\end{tabular}

Notes. Table entries are coefficients; standard errors in parentheses; constant as well as year and party fixed effects included in all models, but omitted from presentation; the scale for party position (dependent variable) is recalibrated from the left-right estimates reported by

102 Ward and Cao 2012, 1092-1094; Ward and Gleditsch 2008, 45. 
the CMP to fit on the 1-10 median voter scale; all explanatory variables are one-year lags; the spatial lags capture parties' policy positions of the year before the last election.

$* \mathrm{p}<0.10 ; * * \mathrm{p}<0.05 ; * * * \mathrm{p}<0.01$

TABLE 2

SPATIAL LONG-TERM EQUILIBRIUM EFFECTS: Wy ${ }^{\text {Incumbent Social Democrats }}$

\begin{tabular}{|c|c|c|c|}
\hline Country & Party & $S P D$ & Labour \\
\hline Austria & Austrian Social Democratic Party & 0.0664 & 0.0664 \\
\hline Belgium & Socialist Party Different & 0.0664 & 0.0664 \\
\hline Belgium & Francophone Socialist Party & 0.0664 & 0.0664 \\
\hline Bulgaria & Coalition for Bulgaria & 0.0664 & 0.0664 \\
\hline Cyprus & Progressive Party of the Working People & 0.0656 & 0.0656 \\
\hline Cyprus & United Democratic Union of Cyprus & 0.0656 & 0.0656 \\
\hline Czech Republic & Czech Social Democratic Party & 0.0672 & 0.0672 \\
\hline Denmark & Social Democratic Party & 0.0672 & 0.0672 \\
\hline Estonia & Social Democratic Party & 0.0672 & 0.0672 \\
\hline Finland & Finnish Social Democrats & 0.0664 & 0.0664 \\
\hline France & Socialist Party & 0.0672 & 0.0672 \\
\hline Germany & Social Democratic Party of Germany & 4.5829 & 0.0664 \\
\hline Greece & Panhellenic Socialist Movement & 0.0672 & 0.0672 \\
\hline Hungary & Hungarian Socialist Party & 0.0664 & 0.0664 \\
\hline Hungary & Hungarian Social Democratic Party & 0.0664 & 0.0664 \\
\hline Ireland & Labour Party & 0.0672 & 0.0672 \\
\hline Luxembourg & Socialist Workers' Party of Luxembourg & 0.0664 & 0.0664 \\
\hline Netherlands & Labour Party & 0.0664 & 0.0664 \\
\hline Norway & Norwegian Labour Party & 0.0664 & 0.0664 \\
\hline Portugal & Socialist Party & 0.0664 & 0.0664 \\
\hline Slovakia & Direction-Social Democracy & 0.0664 & 0.0664 \\
\hline Slovenia & Social Democratic Party & 0.0672 & 0.0672 \\
\hline Spain & Spanish Socialist Workers' Party & 0.0664 & 0.0664 \\
\hline Sweden & Social Democratic Labour Party & 0.0672 & 0.0672 \\
\hline United Kingdom & Labour Party & 0.0664 & 4.5829 \\
\hline
\end{tabular}

Notes. Table entries pertain to spatial long-term equilibrium effects when raising the party policy position of one of the parties highlighted in the last two columns by 1. Entries are based on four decimal places and rounded accordingly. The table only captures a selection of parties and countries in 2010, and not the whole sample. Effects in Columns 1 and 2 are calculated based on one-unit shifts to the right for the German Social Democratic Party (SPD) and the UK Labour Party. 
Table 2 summarizes the findings for the impact of a one-point increase in the positions of the German Social Democrats (SPD) and the UK's Labour Party. We report the median equilibrium impact that incorporates first-order, second-order, and feedback effects, which is based on 1,000 random draws from the multivariate normal distribution of the spatial and temporal lags. The simulations suggest that a one-unit increase in the British Labour Party's policy position would positively affect all other Social Democratic parties in the system. The German SPD, for instance, would react by increasing its policy position by 0.0664 units to the right (accounting for all direct and indirect influences). If the British Labour Party had moved to the right by one unit, the Irish Labour party would have emulated this move by adjusting its position 0.0672 units to the right of its initial left-right placement. Linking these findings to our theory, we find strong and robust support for the Social Democratic Party Family Hypothesis.

We now turn to the comparison of incumbent political parties to the right of the political spectrum. The setup in Table 3 mirrors Model 4 in Table 1 except we now focus on the Christian Democratic and Conservative spatial variables. The Conservative spatial lags are negatively signed, while the coefficient estimates for the Christian Democrat variables are all insignificant (with a varying sign). This suggests that international party policy diffusion does not occur within Christian Democratic or Conservative parties, and that Christian Democratic and Conservative incumbents do not have a special influence either. These findings support our theory: party-family specific cross-national diffusion from successful sister parties is only strong within the Social Democratic family, and it is not a characteristic of right-wing incumbent party families. 
TABLE 3

CHRISTIAN DEMOCRATIC/CONSERVATIVE PARTY FAMILY

\begin{tabular}{lll}
\hline & Model 5 & \multicolumn{1}{c}{ Model 6 } \\
\hline Lagged Party Position & 0.8218 & 0.8235 \\
& $(0.0107)^{* * *}$ & $(0.0107)^{* * *}$ \\
Lagged Median Voter & 0.2715 & 0.2928 \\
& $(0.1105)^{* *}$ & $(0.1106)^{* * *}$ \\
Lagged Economic Globalization & 0.0169 & 0.0181 \\
& $(0.0076)^{* *}$ & $(0.0076)^{* *}$ \\
Lag Median Voter * & -0.0037 & -0.0039 \\
Lagged Economic Globalization & $(0.0015)^{* * *}$ & $(0.0015)^{* * *}$ \\
Wy ${ }^{\text {Domestic }}$ & 0.1512 & 0.1479 \\
Wy ${ }^{\text {Foreign }}$ & $(0.0106)^{* * *}$ & $(0.0105)^{* * *}$ \\
& 0.1472 & 0.1439 \\
Wy Conservatives & $(0.0104)^{* * *}$ & $(0.0104)^{* * *}$ \\
& -0.0032 & \\
Wy ${ }^{\text {Incumbent Conservatives }}$ & $(0.0016)^{* *}$ & \\
Wy Christian Democrats & -0.0012 & \\
Wy Incumbent Christian Democrats & $(0.0020)$ & \\
Observations & & -0.0010 \\
Year and Party Fes & & $(0.0010)$ \\
\hline
\end{tabular}

Notes. Table entries are coefficients; standard errors in parentheses; constant as well as year and party fixed effects included, but omitted from presentation; the scale for party position (dependent variable) is recalibrated from the left-right estimates reported by the CMP to fit on the 1-10 median voter scale; all explanatory variables are one-year lags, the spatial lags capture parties' policy positions of the year before the last election.

$* \mathrm{p}<0.10 ; * * \mathrm{p}<0.05 ; * * * \mathrm{p}<0.01$ 
Finally, the results concerning the control variables mirror previous research. ${ }^{103}$ First, the coefficients of the domestic-level spatial lag, $\mathbf{W y}{ }^{\text {Domestic }}$, and of the foreign-level spatial lag, $\mathbf{W} y^{\text {Foreign }}$, have positive estimates, which emphasizes that parties learn from and emulate not only rival parties, but also other political parties in other countries. This replicates Adams and Somer-Topcu, Williams, and Böhmelt et al. ${ }^{104}$ Second, economic globalization conditions the effect of the median voter on parties' policy positions. The coefficient of the interaction between these two variables shows that the further to the left the median voter, the more globalization pushes parties' positions to the right. ${ }^{105}$

In the SI, we give an overview of the parties that are coded as Social Democratic (Table A1) and we discuss a number of additional analyses. First, we take the size of a source or "sending" party's country into account, as it may be plausible that parties, also Social Democratic ones, are more likely to learn from parties in larger states (Table A2). Second, we control for inflation and GDP growth as additional economic influences (Table A3). Third, we model thoroughly systemic changes in the international context, which may affect party policy positions, by accounting for Cold-War developments and EU membership. We also examine whether diffusion within the Social Democratic party family changed over time, given its "Third Way" turn discussed above, by restricting our analysis to the pre-2000 period (Tables A4 and A5). Fourth, we test the robustness of our findings after adjusting for uncertainty around the estimates of party position (Table A6). Fifth, we control for the presence of more than one Social Democratic party in a focal country, we aggregate Christian Democrats and Conservatives into one party group (i.e., an "ideological bloc"), and we consider parties to the left of the Social Democrats (rather than the right) as our reference point (Tables A7 to A9). Sixth, we address the argument that Social Democratic parties

\footnotetext{
${ }^{103}$ For example, Adams and Somer-Topcu 2009; Williams 2015; Ward et al. 2011.

104 Adams and Somer-Topcu 2009; Williams 2015; Böhmelt et al. 2016; 2017.

105 Ward et al. 2011.
} 
compete in a two-dimensional political space. For instance, these parties' progressive positions on the cultural dimension of competition ${ }^{106}$ may have "alienated the core constituency of Social Democracy, the working class." ${ }^{\text {"107 }}$ Our main analyses focus on the left-right scale and, thus, a one-dimensional issue space. In the SI, we account for the existence of a multidimensional issue space in two ways: we first omit and then control for countries that are likely characterized by only one dimension (Table A10); ${ }^{108}$ next, we examine the diffusion of party policy positions on an issue that the literature identifies as part of the second dimension (Table A11). Following recent work, ${ }^{109}$ we analyze a second dimension using party positions on European integration. Both analyses confirm that Social Democratic party policy diffusion is exceptional - not just for the left-right policies - but also for European integration. Finally, we focus more closely on the relevance of the two diffusion pathways that our theory identifies - Social Democracy's institutional linkages and shared challenges - for the exceptional level of policy diffusion within this party family. We shed light on the centrality of strong transnational institutional links to the exceptional level of policy diffusion among Social Democrats by studying the impact of membership in the EP's PES group (Table A12). To model the effect of the unique cross-national challenges facing Social Democratic parties, we interact $\mathbf{W y}$ Incumbent Social Democrats $^{\text {with the globalization item and }}$ examine whether diffusion rates increase in the magnitude of the challenge, as measured by levels of globalization (Table A13 and Figure A1). The results of all of these additional analyses support the Social Democratic Party Family Hypothesis.

\section{CONCLUSION}

\footnotetext{
${ }^{106}$ Kitschelt 1994.

${ }^{107}$ Abou-Chadi and Wagner 2020, 247.

108 Based on Benoit and Laver 2006; Table A10.

${ }^{109}$ Abou-Chadi and Wagner 2020; Whitefield and Rohrschneider 2019.
} 
We theorize that party family becomes an important channel for policy learning from and emulating successful sister parties abroad when it features strong transnational organizational ties and faces unique and powerful challenges. Both of these factors identify Social Democratic parties as exceptional compared to the other major party families, in particular Christian Democratic and Conservative parties. Our empirical findings provide strong and robust evidence for the Social Democratic Party Family Hypothesis that crossnational policy diffusion is more likely to occur from successful incumbents within the Social Democratic family than within other party families. This result makes contributions to four important literatures in political science.

First, for work on programmatic policy diffusion, we clarify under which conditions party families are (and are not) consequential for transnational policy emulation. ${ }^{110}$ Second, to the studies of Social Democracy, we add a systematic theoretical and empirical account of the exceptional amount of policy learning that has occurred across borders from successful parties within this family since the mid-1970s in contrast to other major party families. This analysis complements other prominent research, which emphasizes the uniqueness of this party family. ${ }^{111}$ Third, with respect to the literature on political parties' election strategies, we highlight that parties can be powerfully influenced by sister parties abroad. This adds an international dimension to a body of work that otherwise naturally gravitates toward domestic-level explanations. ${ }^{112}$ Finally, to the extent that Social Democratic parties account for a significant share of the incumbents that then influence governing policies, our research has broader implications for the literature on policy diffusion. ${ }^{113}$ Among Social Democrats, as

\footnotetext{
${ }^{110}$ Gallagher et al. 2011.

${ }^{111}$ Kitschelt 1994; Przeworski and Sprague 1986; see also Adams et al. 2009.

112 Abou-Chadi and Orlowski 2016; Adams and Merrill 2009; Meguid 2008; Spoon 2011; see also Erikson et al. 2002.

${ }^{113}$ Elkins and Simmons 2005; Gilardi 2010; 2012.
} 
we show, party family is a channel that facilitates the emulation of and learning from policies adopted by foreign incumbents, in contrast to Christian Democrats and Conservatives.

This article also raises several questions for future research. For example, our theory suggests that the continuing unique and existential challenges that have driven the decline of Social Democracy generate strong incentives for cross-national emulation within this family of future programmatic choices that prove capable of carrying Social Democrats back to power. It may also be interesting to conduct analyses of policy diffusion within party families on more narrowly defined issue dimensions than the left-right, such as immigration or the environment. The success of populist challengers, for instance, may be a by-product of crossnational policy transmission on the specific dimension of immigration within this bloc.

The role of party organization also deserves further attention. Schumacher, De Vries, and Vis ${ }^{114}$ claim that the balance-of-power between party activists and party leaders affects parties' policy shifts. ${ }^{115}$ Hierarchical parties may be more active in engaging in policy diffusion processes, since leaders have more authority to adopt successful party strategies. Alternatively, internally democratic and less hierarchical parties could develop more channels for emulation through transnational ties between their supporters. ${ }^{116}$ Depending on which intraparty mechanism is at work, there will be important consequences for our future understanding of how party policy diffusion occurs. To generate a complete understanding of cross-border policy learning within party families, our quantitative study would also benefit from complementary qualitative and process-oriented comparisons to observe specific interactions (or the lack thereof) between party elites.

\footnotetext{
${ }^{114}$ Schumacher, De Vries, and Vis 2013.

115 See also Lehrer 2012.

${ }^{116}$ Ceron 2012; Lehrer et al. 2017.
} 
Finally, while much of the established literature concentrates on the cross-border diffusion of policies from one government to another, ${ }^{117}$ we add support to the claim that parties' policy positions also travel across countries. This finding has importance because parties' manifesto "rhetoric" usually precedes legislative action. ${ }^{118}$ That said, a more comprehensive analysis of how levels of diffusion interact is required (i.e., how diffusion works across voters, parties, and governing policies). For example, it may be plausible that political parties react especially strongly to governing parties' concrete policy outputs (though, arguably, these may be based on their manifesto pledges). The notion that governing parties' policy outputs could be influential is straightforward, and it is consistent with research showing that voters are more likely to update their perceptions of governing parties vs. opposition parties. ${ }^{119}$ If voters are more attentive to incumbents, this would also suggest that policy diffusion will occur more readily from successful political parties and the subsequent policy outputs they legislate.

We conclude that our findings open several avenues for future research and contribute to a more nuanced understanding of Social Democracy, party families, parties' election strategies, and policy diffusion. Social Democratic party family is unique because incumbents have an exceptional level of influence on their sister parties' policies abroad.

\section{REFERENCES}

Abou-Chadi, Tarik, and Matthias Orlowski. 2016. "Moderate as Necessary: The Role of Electoral Competitiveness and Party Size in Explaining Parties' Policy Shifts." Journal of Politics 78, no. 3: 868-881. doi: 10.1086/685585.

117 See Gilardi 2010; 2012.

${ }^{118}$ See also Böhmelt et al. 2016.

${ }^{119}$ Adams et al. 2020; Bernardi and Adams 2019; Soroka and Wlezien 2010. 
Abou-Chadi, Tarik, and Markus Wagner. 2020 "Electoral Fortunes of Social Democratic Parties: Do Second Dimension Positions Matter?” Journal of European Public Policy 27, no. 2: 246-272. doi: 10.1080/13501763.2019.1701532.

Adams, James. 2001. “A Theory of Spatial Competition with Biased Voters: Party Policies Viewed Temporally and Comparatively.” British Journal of Political Science 31, no. 1: 121158. doi:10.1017/S0007123401000060.

Adams, James, Luca Bernardi, and Christopher Wlezien. 2020. "Social Welfare Policy Outputs and Governing Parties' Left-Right Images: Do Voters Respond?” Journal of Politics 82, no. 3: 1161-1165. doi: 10.1086/707523.

Adams, James, Lawrence Ezrow, and Christopher Wlezien. 2016. “The Company You Keep: How Voters Infer Party Positions on European Integration from Governing Coalition Arrangements.” American Journal of Political Science 60, no. 4: 811-823. doi: 10.1111/ajps.12231.

Adams, James, Samuel Merrill III, and Bernard Grofman. 2005. A Unified Theory of Party Competition: A Cross-National Analysis Integrating Spatial and Behavioral Factors. New York: Cambridge University Press.

Adams, James, and Samuel Merrill. 2009. "Policy-Seeking Parties in a Parliamentary Democracy with Proportional Representation: A Valence-Uncertainty Model.” British Journal of Political Science 39, no. 3: 539-558. doi: 10.1017/S0007123408000562. Adams, James, and Zeynep Somer-Topcu. 2009. "Do Parties Adjust their Policies in Response to Rival Parties' Policy Shifts? Spatial Theory and the Dynamics of Party Competition in Twenty-Five Democracies.” British Journal of Political Science 39, no. 4: 825-846. doi: 10.1017/S0007123409000635. 
Aragonès, Enriqueta, Micael Castanheira, and Marco Giani. 2015. "Electoral Competition through Issue Selection.” American Journal of Political Science 59, no. 1: 71-90. doi: 10.1111/ajps.12120.

Bawn, Kathleen, and Zeynep Somer-Topcu. 2012. "Government versus Opposition at the Polls: How Governing Status Affects the Impact of Policy Positions." American Journal of Political Science 56, no. 2: 433-446. doi: 10.1111/j.1540-5907.2011.00563.x.

Benedetto, Giacomo, Simon Hix, and Nicola Mastrorocco. 2020. "The Rise and Fall of Social Democracy, 1918-2017.” American Political Science Review 114, no. 3: 928-939. doi: $10.1017 / \mathrm{S} 0003055420000234$

Berman, Sheri, and Maria Snegovaya. 2019. "Populism and the Decline of Social Democracy." Journal of Democracy 30, no. 3: 5-19. doi: 10.1353/jod.2019.0038.

Bernardi, Luca, and James Adams. 2019. "Does Government Support Respond to Governments' Social Welfare Rhetoric or their Spending? An Analysis of Government Support in Britain, Spain, and the United States." British Journal of Political Science 49, no. 4: 1407-1429. doi: 10.1017/S0007123417000199.

Blair, Tony, and Gerhard Schröder. 1999. Europe: The Third Way/Die Neue Mitte. Available online: https://library.fes.de/pdf-files/bueros/suedafrika/02828.pdf (accessed on December 3, 2020).

Böhmelt, Tobias, Lawrence Ezrow, Roni Lehrer, and Hugh Ward. 2016. "Party Policy Diffusion." American Political Science Review 110, no. 2: 397-410. doi: $10.1017 / \mathrm{S} 0003055416000162$.

Böhmelt, Tobias, Lawrence Ezrow, Roni Lehrer, Petra Schleiter, and Hugh Ward. 2017. "Why Dominant Governing Parties Are Cross-Nationally Influential." International Studies Quarterly 61, no. 4: 749-759. doi: 10.1093/isq/sqx067. 
Budge, Ian. 1994. “A New Spatial Theory of Party Competition: Uncertainty, Ideology, and Policy Equilibria Viewed Comparatively and Temporarily." British Journal of Political Science 24, no. 4: 443-468. doi: 10.1017/S0007123400006955.

Budge, Ian, Hans Keman, Michael McDonald, and Paul Pennings. 2012. Organizing Democratic Choice: Party Representation over Time. Oxford: Oxford University Press. Budge, Ian, Hans-Dieter Klingemann, Andrea Volkens, Judith Bara, and Eric Tanenbaum. 2001. Mapping Policy Preferences: Estimates for Parties, Electors, and Governments 1945 1998. Oxford: Oxford University Press.

Buhaug, Halvard, and Kristian Skrede Gleditsch. 2008. "Contagion or Confusion? Why Conflicts Cluster in Space.” International Studies Quarterly 52, no. 2: 215-233. doi: 10.1111/j.1468-2478.2008.00499.x.

Calvo, Ernesto, and Maria Victoria Murillo. 2019. Non-Policy Politics: Richer Voters, Poorer Voters, and the Diversification of Electoral Strategies. New York, NY: Cambridge University Press.

Ceron, Andrea. 2012. "Bounded Oligarchy: How and When Factions Constrain Leaders in Party Position-Taking.” Electoral Studies 31, no. 4: 689-701. doi:

10.1016/j.electstud.2012.07.004.

Dolowitz, David, Stephen Greenwold, and David Marsh. 1999. “Policy Transfer: Something Old, Something New, Something Borrowed, But Why Red, White and Blue?" Parliamentary Affairs 52, no. 4: 719-730. doi: 10.1093/pa/52.4.719.

Dolowitz, David, and David Marsh. 2000. "Learning from Abroad: The Role of Policy Transfer in Contemporary Policy-Making." Governance 13, no. 1: 5-24. doi: 10.1111/09521895.00121.

Döring, Holger, and Philip Manow. 2012. Parliament and Government Composition Database (ParlGov): An Infrastructure for Empirical Information on Parties, Elections, and 
Governments in Modern Democracies. Version 12/10 - 15 October 2012. Available online: http://parlgov.org/ (accessed on December 3, 2020).

Dreher, Axel. 2006. "Does Globalization Affect Growth? Evidence from a New Index of Globalization.” Applied Economics 38, no. 10: 1091-1110. doi:

$10.1080 / 00036840500392078$.

Elkins, Zachary, and Beth Simmons. 2005. "On Waves, Clusters, and Diffusion: A Conceptual Framework." Annals of the American Academy of Political and Social Science 598, no. 1: 33-51. doi: 10.1177/0002716204272516.

Erikson, Robert, Michael MacKuen, and James Stimson. 2002. The Macro Polity. Cambridge: Cambridge University Press.

Evans, Geoffrey, and Stephen Whitefield. 1993. "Identifying the Bases of Party Competition in Eastern Europe." British Journal of Political Science 23, no. 4: 521-548. doi: 10.1017/S0007123400006712.

Evans, Geoffrey, and Stephen Whitefield. 1998. "The Evolution of Left and Right in PostSoviet Russia.” Europe-Asia Studies 50, no. 6: 1023-1042. doi:

$10.1080 / 09668139808412579$.

Ezrow, Lawrence, Tobias Böhmelt, Roni Lehrer, and Hugh Ward. 2020. "Follow the Foreign Leader? Why Following Foreign Incumbents is an Effective Electoral Strategy." Party Politics: Forthcoming.

Franzese, Robert, and Jude Hays. 2007. "Spatial Econometric Models of Cross-Sectional Interdependence in Political Science Panel and Time-Series-Cross-Section Data." Political Analysis 15, no. 2: 140-164. doi: 10.1093/pan/mpm005.

Franzese, Robert, and Jude Hays. 2008. "Interdependence in Comparative Politics:

Substance, Theory, Empirics, Substance.” Comparative Political Studies 41, no. 4/5: 742780. doi: $10.1177 / 0010414007313122$. 
Gallagher, Michael, Michael Laver, and Peter Mair. 2011. Representative Government in Modern Europe. London: McGraw-Hill.

Giddens, Anthony. 1998. The Third Way: The Renewal of Social Democracy. Cambridge: Polity Press.

Giddens, Anthony. 2000. The Third Way and Its Critics. Cambridge, MA: Polity Press.

Gilardi, Fabrizio. 2010. "Who Learns From What In Policy Diffusion Processes?” American Journal of Political Science 54, no. 3: 650-666. doi: 10.1111/j.15405907.2010.00452.x.

Gilardi, Fabrizio. 2012. “Transnational Diffusion: Norms, Ideas, and Policies.” In: Walter Carlsnaes, Thomas Risse, and Beth Simmons (eds.). Handbook of International Relations. Thousand Oaks, CA: Sage, 453-477.

Green-Pedersen, Christoffer, Peter Mortensen, and Gunnar Thesen. 2017. "The Incumbency Bonus Revisited: Causes and Consequences of Media Dominance.” British Journal of Political Science 47, no. 1: 131-148. doi: 10.1017/S0007123415000022.

Harbers, Imke, Catherine De Vries, and Marco Steenbergen. 2013. “Attitude Variability Among Latin American Publics: How Party System Structuration Affects Left/Right Ideology.” Comparative Political Studies 46, no. 8: 947-967. doi:

$10.1177 / 0010414012454409$.

Hays, Jude, Aya Kachi, and Robert Franzese. 2010. “A Spatial Model Incorporating Dynamic, Endogenous, Network Interdependence: A Political Science Application.” Statistical Methodology 7, no. 3: 406-428. doi: 10.1016/j.stamet.2009.11.005.

Hearl, Derek. 2001. “Checking the Party Policy Estimates: Reliability.” In: Ian Budge, Hans-Dieter Klingemann, Andrea Volkens, Judith Bara, and Eric Tanenbaum (eds.). 2001. Mapping Policy Preferences: Estimates for Parties, Electors, and Governments 1945-1998. Oxford: Oxford University Press, 111-125. 
Hix, Simon. 1996. “The Transnational Party Federations.” In: John Gaffney (ed.), Political Parties and the European Union. London: Routledge, 308-331.

Hopmann, David, Christian Elmelund-Præstekær, Erik Albæk, Rens Vliegenthart, and Claes H. de Vreese. 2012. "Party Media Agenda-Setting: How Parties Influence Election News Coverage.” Party Politics 18, no. 2: 173-191. doi: 10.1177/1354068810380097.

Huber, John, and Ronald Inglehart. 1995. "Expert Interpretations of Party Space and Party Locations in 42 Societies." Party Politics 1, no. 1: 73-111. doi:

$10.1177 / 1354068895001001004$.

Huber, John, and Bingham Powell. 1994. "Congruence between Citizens and Policymakers in Two Visions of Democracy." World Politics 46, no. 3: 291-326. doi: $10.2307 / 2950684$.

Imlay, Talbot C. 2018. The Practice of Socialist Internationalism: European Socialists and International Politics, 1914-1960. Oxford: Oxford University Press.

Jacobs Francis (ed.). 1989. Western European Political Parties: A Comprehensive Guide. Harlow: Longman.

Kahneman, Daniel, Paul Slovic, and Amos Tversky (eds.). 1982. Judgment under Uncertainty: Heuristics and Biases. Cambridge: Cambridge University Press.

Kalyvas, Sthathis, and Kees Van Kersbergen. 2010. “Christian Democracy.” Annual Review of Political Science 13, no. 1: 183-209. doi:

10.1146/annurev.polisci.11.021406.172506.

Kang, Shin-Goo, and Bingham Powell. 2010. "Representation and Policy Responsiveness: The Median Voter, Election Rules, and Redistributive Welfare Spending." Journal of Politics 72, no. 4: 1014-1028. doi: 10.1017/S0022381610000502.

Keman, Hans. 2011. “Third Ways and Social Democracy: The Right Way to Go?” British Journal of Political Science 41, no. 3: 671-680. doi: 10.1017/S0007123410000475. 
Kitschelt, Herbert. 1994. The Transformation of European Social Democracy. Cambridge: Cambridge University Press.

Klingemann, Hans-Dieter, Andrea Volkens, Judith Bara, Ian Budge, and Michael McDonald. 2006. Mapping Policy Preferences II: Estimates for Parties, Electors, and Governments in Central and Eastern Europe, European Union, and OECD 1990-2003. Oxford: Oxford University Press.

Ladrech, Robert. 1993. "Social democratic parties and EC integration: Transnational party responses to Europe 1992." European Journal of Political Research 24, no. 2: 195-210. 93. doi: 10.1111/j.1475-6765.1993.tb00376.x.

Laver, Michael. 2005. "Policy and the Dynamics of Political Competition.” American Political Science Review 99, no. 2: 263-281. doi: 10.1017/S0003055405051646.

Laver, Michael, Kenneth Benoit, and John Garry. 2003. "Estimating the Policy Positions of Political Actors Using Words as Data.” American Political Science Review 97, no. 2: 311331. doi: $10.1017 / \mathrm{S} 0003055403000698$.

Laver, Michael, and Ernest Sergenti. 2012. Party Competition: An Agent Based Model. Princeton, NJ: Princeton University Press.

Layton-Henry, Zig (ed.). 1982. Conservative Politics in Western Europe. London: Palgrave Macmillan.

Lehrer, Roni. 2012. "Intra-Party Democracy and Party Responsiveness.” West European Politics 35, no. 6: 1295-1319. doi: 10.1080/01402382.2012.713747.

Lehrer, Roni, Lawrence Ezrow, Hugh Ward, and Tobias Böhmelt. 2017. “Intra-Party Democracy and Responsiveness to Rival Parties’ Policies.” Social Science Quarterly 98, no. 3: 1026-1044. doi: 10.1111/ssqu.12432.

Linzer, Drew. 2008. The Structure of Mass Ideology and Its Consequences for Democratic Governance. University of California at Los Angeles: PhD Dissertation. 
Lo, James, Sven-Oliver Proksch, and Jonathan Slapin. 2016. "Ideological Clarity in Multiparty Competition: A New Measure and Test Using Election Manifestos.” British Journal of Political Science 46, no. 3: 591-610. doi: 10.1017/S0007123414000192. Markowski, Radoslaw. 1997. "Political Parties and Ideological Spaces in East Central Europe." Communist and Post-Communist Studies 30, no. 3: 221-254. doi: 10.1016/S0967067X(97)00006-8.

Marks, Gary, Liesbet Hooghe, Moira Nelson, and Erica Edwards. 2006. "Party Competition and European Integration in the East and West: Different Structure, Same Causality." Comparative Political Studies 39, no. 2: 155-175. doi: $10.1177 / 0010414005281932$.

McAllister, Ian, and Stephen White. 2007. "Political Parties and Democratic Consolidation in Post-Communist Societies." Party Politics 13, no. 2: 197-216. doi: $10.1177 / 1354068807073858$.

McDonald, Michael, and Ian Budge. 2005. Elections, Parties, Democracy: Conferring the Median Mandate. Oxford: Oxford University Press.

McDonald, Michael, and Silvia Mendes. 2001. "Checking the Party Policy Estimates: Convergent Validity.” In: Ian Budge, Hans-Dieter Klingemann, Andrea Volkens, Judith Bara, and Eric Tanenbaum (eds.). 2001. Mapping Policy Preferences: Estimates for Parties, Electors, and Governments 1945-1998. Oxford: Oxford University Press, 127-141.

Meguid, Bonnie M. 2005. “Competition between Unequals: The Role of Mainstream Party Strategy in Niche Party Success." American Political Science Review 99, no. 3: 347-359. doi: 10.1017/S0003055405051701.

Meguid, Bonnie. 2008. Party Competition between Unequals: Strategies and Electoral Fortunes in Western Europe. Cambridge: Cambridge University Press. 
Plümper, Thomas, and Eric Neumayer. 2010. "Model Specification in the Analysis of Spatial Dependence.” European Journal of Political Research 49, no. 3: 418-442. doi: 10.1111/j.1475-6765.2009.01900.x.

Plümper, Thomas, Vera Troeger, and Philip Manow. 2005. "Panel Data Analysis in Comparative Politics.” European Journal of Political Research 44, no. 2: 327-354. doi: 10.1111/j.1475-6765.2005.00230.x.

Pontusson, Jonas. 1995. "Explaining the Decline of European Social Democracy: The Role of Structural Economic Change." World Politics 47, no. 4: 495-533. doi: 10.1017/S0043887100015197.

Pop-Eleches, Grigore, and Joshua A. Tucker. 2011 “Communism’s Shadow:

Postcommunist Legacies, Values, and Behavior." Comparative Politics 43, no. 4: 379-408. doi: $10.5129 / 001041511796301588$.

Powell, Bingham. 2000. Elections as Instruments of Democracy: Majoritarian and Proportional Visions. New Haven, CT: Yale University Press.

Przeworski, Adam, and John Sprague. 1986. Paper Stones: A History of Electoral Socialism. Chicago, IL.: Chicago University Press.

Schmitt, Herman, and Evi Scholz. 2005. The Mannheim Eurobarometer Trend File, 19702002. Ann Arbor, MI: Inter-University Consortium for Political and Social Research. doi: 10.3886/ICPSR03384.

Schoenbacher, Klaus, Jan de Ridder, and Edmund Lauf. 2001. "Politicians on TV News: Getting Attention in Dutch and German Election Campaigns." European Journal of Political Research 39, no. 4: 519-531. doi: 10.1111/1475-6765.00586.

Schumacher, Gijs, Catherine De Vries, and Barbara Vis. 2013. "Why Political Parties Change Their Position: Environmental Incentives and Party Organization.” Journal of Politics 75, no. 2: 464-477. doi: 10.1017/S0022381613000145. 
Seidelman, Reimund. 1998. “The Socialist International.” Friedrich Ebert Stiftung. Available online: http://library.fes.de/pdf-files/bueros/suedafrika/02827.pdf (accessed on December 3, 2020).

Semetko, Holli. 1996. "Political Balance on Television. Campaigns in the United States, Britain, and Germany." International Journal of Press/Politics 1, no. 1: 51-71. doi: 10.1177/1081180X96001001005.

Senninger, Roman, Daniel Bischof, and Lawrence Ezrow. 2020. "How Transnational Party Alliances Influence National Parties' Policies.” Political Science Research and Methods: Forthcoming. doi: 10.31235/osf.io/rkgmc.

Somer-Topcu, Zeynep. 2009. “Timely Decisions: The Effects of Past National Elections on Party Policy Change." Journal of Politics 71, no. 1: 238-248. doi: $10.1017 / \mathrm{S} 0022381608090154$.

Somer-Topcu, Zeynep. 2015. "Everything to Everyone: The Electoral Consequences of the Broad-Appeal Strategy in Europe.” American Journal of Political Science 59, no. 4: 841854. doi: 10.1111/ajps.12165.

Soroka, Stuart N., and Christopher Wlezien. 2010. Degrees of Democracy: Politics, Public Opinion, and Policy. Cambridge: Cambridge University Press.

Spoon, Jae-Jae. 2011. Political Parties of Small Parties in Europe. Ann Arbor, MI: University of Michigan Press.

Stokes, Donald. 1992. "Valence Politics.” In: Dennis Kavanagh (Ed.), Electoral Politics. Oxford: Clarendon Press, 141-164.

Strøm, Kaare. 1990. “A Behavioral Theory of Competitive Political Parties.” American Journal of Political Science 34, no. 2: 565-598. doi: 10.2307/2111461.

Tversky, Amos, and Daniel Kahneman. 1974. “Judgment under Uncertainty: Heuristics and Biases." Science 185, no. 4157: 1124-1131. doi: 10.1126/science.185.4157.1124. 
Tversky, Amos, and Daniel Kahneman. 1979. "Prospect Theory: An Analysis of Decision Under Risk.” Econometrica 47, no. 2: 263-291. doi: 10.2307/1914185.

Tversky, Amos, and Daniel Kahneman. 1982. "Judgment under Uncertainty: Heuristics and Biases.” In: Amos Tversky and Daniel Kahneman (eds.) Judgment Under Uncertainty: Heuristics and Biases. Cambridge: Cambridge University Press, 3-22.

Van Kersbergen, Kees, and Philip Manow. (Eds.). 2009. Religion, Class Coalitions, and Welfare States. Cambridge: Cambridge University Press.

Volkens, Andrea, Pola Lehmann, Nicolas Merz, Sven Regel, and Annika Werner. 2013. The Manifesto Data Collection. Manifesto Project (MRG/CMP/MARPOR). Version 2013a. Berlin: Wissenschaftszentrum Berlin für Sozialforschung (WZB). doi: 10.25522/manifesto.mpds.2013a.

Von Beyme, Klaus. 1985. Political Parties in Western Democracies. New York: St. Martin's Press.

Ward, Hugh, and Xun Cao. 2012. "Domestic and International Influences on Green Taxation." Comparative Political Studies 45, no. 9: 1075-1103. doi: 10.1177/0010414011434007.

Ward, Hugh, Lawrence Ezrow, and Han Dorussen. 2011. "Globalization, Party Positions, and the Median Voter." World Politics 63, no. 3: 509-547. doi:

10.1017/S004388711100013X.

Ward, Michael, and Kristian Skrede Gleditsch. 2008. Spatial Regression Models. London: Sage Publications.

Ware, Alan. 1996. Political Parties and Party Systems. Oxford: Oxford University Press. Warwick, Paul. 2002. “Toward a Common Dimensionality in West European Policy Spaces.” Party Politics 8, no. 1: 101-122. doi: 10.1177/1354068802008001005. 
Weyland, Kurt. 2005. "Theories of Policy Diffusion Lessons from Latin American Pension Reform.” World Politics 57, no. 2: 262-295. doi: 10.1353/wp.2005.0019.

Williams, Laron. 2015. "It's All Relative: Spatial Positioning of Parties and Ideological Shifts." European Journal of Political Research 54, no. 1: 141-159. doi: 10.1111/14756765.12063.

Williams, Laron, and Guy Whitten. 2015. “Don't Stand So Close to Me: Spatial Contagion Effects and Party Competition.” American Journal of Political Science 59, no. 2: 309-325. doi: 10.1111/ajps.12124.

Williams, Laron, Katsunori Seki, and Guy Whitten. 2016. "You've Got Some Explaining to Do: The Influence of Economic Conditions and Spatial Competition on Party Strategy." Political Science Research and Methods 4, no. 1: 47-63. doi: 10.1017/psrm.2015.13.

Wittman, Donald. 1983. "Candidate Motivation: A Synthesis of Alternative Theories." American Political Science Review 77, no. 1: 142-157. doi: 10.2307/1956016. 